\title{
Sadah: Aesthetical Quality of Talempong Sound- An Acoustical Study of Myth and Ontological Culture
}

\author{
Andar Indra Sastra Wilma Sriwulan Yonhedri \\ Lecturer in Karawitan Study Program Indonesian Institute of the Arts (ISI) Padangpanjang, Indonesia
}

\begin{abstract}
The goal of this research is to discover the effect of sadah (chalk) on the aesthetical quality of talempong sound (a bronze musical instrument). In order to preserve the aesthetical quality of talempong sound, talempong elders in Minangkabau use a solution of sadah (a type of chalk commonly used in betel chewing). The sadah solution is smeared onto the inside of the talempong - the resonating chamber - to achieve a particular standard of aesthetical quality. Here, aesthetical quality refers to the musical taste measured and owned by talempong elders; this includes talempong as a music system and talempong as a musical system - both of which begin with form and sound. Form and sound are an inseparable unit, and for this reason the physical quality - form - of the talempong is significant in obtaining a talempong sound with a particular aesthetical quality. The significance of aesthetical quality is determined by the sound colour (rono) and duration of the reverberation or sound resonating from the talempong when struck, which talempong elders call dangiang. The method used in this research combines qualitative principles with an experimental method. The experimental method is used to discover the sound quality of the talempong before and after it has been smeared with sadah.
\end{abstract}

Keywords: sadah, aesthetical quality, talempong sound, acoustic

DOI: $10.7176 / \mathrm{ADS} / 75-02$

Publication date: August $31^{\text {st }} 2019$

\section{Introduction}

Sadah is a type of chalk that is made from a shell and often referred to as 'sadah for eating' since it is used in betel chewing which in the past was a common practice among the women of Minangkabau. The chemical reaction produced by combining sadah, gambir, areca nut, and betel leaf gives a unique pleasurable sensation to the person chewing, as well as staining the lips and tongue red. A solution of dissolved sadah chalk is also used by talempong elders in Minangkabau to obtain a particular aesthetical quality in the sound colour (rono) of this bronze musical instrument. The type of rono considered good in talempong is one that is "round and short" and resonates well (is not pakak). According to Suka Harjana, "round and short" describes a dimension of sound and form that is influenced by its source (Hardjana, 1983: 52). Pakak is another dimension of sound that fails to produce a sound that matches the rono of the talempong.

It is important to preserve and maintain a good rono and character of talempong sound so that the duration of the reverberation or resonance (sipongang) is not too long. Talempong elders in Minangkabau have a special way of ensuring a good rono and sipongang. They use the concept of manyadahi (applying sadah), smearing a solution of dissolved chalk onto the inside of the talempong, in accordance with the sound condition of each instrument. The practice of "manyadahi talempong" is performed in a simple ritual with a number of special requirements. The requirements or concoction used include: (1) limau/asamkapeh or lime fruit; (2) aiabatamu, or water that is taken from two different springs which meet and become one at a particular place; (3) aiamalampatang Kamih; malam Jumaik, or water from a spring that is collected on a Thursday evening; and (4) sadah, a type of chalk made from snail shells which is usually known as "sadah for eating" because of its use in betel chewing.

The physical quality of the talempong is important with regard to its function both as a sound source and a resonating chamber. The sound source is the bossed knob (momong or pencon) on top of the talempong. A sound is produced when a special wooden mallet (pangguguah) strikes the momong with a particular force. When the momong produces a sound, the whole talempong vibrates. This vibration causes the air around the sound source to vibrate. The vibration in the air caused by the momong is influenced by the resonating chamber, or the physical shape of the cavity inside the talempong. The resonating chamber and physical quality have a relational connection in terms of their function to produce an aesthetical quality in the sound of a particular talempong or a set of talempong instruments. A set of talempong, usually known as salabuhan, consists of 6 talempong instruments with 6 different pitches, which make up a single music system. In this research, they are referred to as T1, T2, T3, T4, T5, and T6. The problem discussed in this research is related to the procedure and method for smearing the talempong with sadah (manyadahi talempong), and the effect of sadah on creating an aesthetical quality of talempong sound that is pleasing to the ear.

\section{Literature Study}

The various literature related to this research includes Suka Hardjana's book Estetika Musik (1983). In principle, 
this book discusses the understanding of aesthetics, the understanding of music, and the understanding of musical aesthetics, or music and beauty. In the section on music and beauty, Suka Hardjana discusses in detail various aspects of sound, including the anatomy of sound, tone, noise, and pitch. These four main topics cover: volume and intensity of sound, dynamics and vitality of sound, duration, range, sound quality, sound form, sound colour, and so on. In the discussion on sound form, he explains that a sound form that is short and round is a dimension of sound and form which is influenced by its source.

Andar Indra Sastra (2016), in his work Estetika Talempong Renjeang, discusses aesthetics in the performance of talempong renjeang in an attempt to reintroduce the potential of local culture through the concept of batalun. The concept of batalun as a phenomenon that provides an aesthetical flavour to the performance of talempong renjeanganamsalabuhan (a set of six instruments that are carried by hand) in Luhak Nan Tigo Minangkabau, is an endeavour to "revive the submerged stem" of the power of hegemony that changed the course of aesthetical flavour of talempong as a music system and talempong as a musical system known locally as mangkoanbunyi (the system for tuning talempong).

In an article published in Jurnal Humaniora, Andar Indra Sastra (2017) explores the concept of talempong renjeang music which is made up of three pairs of talempong instruments: talempong Jantan, talempong Paningkah, and talempong Pangawinan. As the 'leader', the talempong Jantan maintains the consistency and integrity of the theme and danyuik (tempo) of the music, while the talempong Paningkah follows the path of the talempong Jantan, using different playing motifs, and the talempongPangawinan has the role and authority for making the talempong tune (guguah) whole and forming the melody.

Sri Hastanto (2012), in his book entitled Ngeng \& Reng: Persandingan Sistem Pelarasan Gamelan Ageng Jawa Dan Gong Kebyar Bali Ngeng \& Reng: Persandingan Sistem Pelarasan Gamelan Ageng Jawa Dan Gong Kebyar Bali, includes a discussion on the science of acoustics. He writes that the distance between two pitches, known conventionally as an interval, is measured using a system of cents. This distance can be measured by means of a logarithmical calculation, with the aid of computer technology which uses the German software Sengpielaudio.

The Liang Gie (1983), in his book Garis Estetik-Filsafat Keindahan, discusses the phenomenon and aesthetical experience of an object that exudes aesthetical value. He explains that aesthetical value is the ability of an object to cause an aesthetical experience in the person observing or listening to the object. Manyadahi talempong is part of an aesthetical experience for ensuring that the sound produced is pleasing to the ear.

Deni Junaiedi (2018) writes about the definition of aesthetics, and the scope of his study includes the parameters of 'attractiveness' and 'unattractiveness' in the subject's experience of an object and its aesthetical value. Martin Suryajaya (2015),in his book entitled Sejarah Estetika: Era Klasik Sampai Kontemporer, explains the term "aesthetic" in etymological terms. The noun form aesthesis refers to sensory perception which includes sight, sound, and also feeling.

Fatchur Rochman (1995), in his work Kisah-Kisah Nyata dalam Al-Qur'an, provides an important reference about the miracle or gift of the prophet David. It is wellknown that the prophet David had the gift of a voice that sounded sweet and pleasing to the ear of humans and spirits alike. This is the philosophical - mythological basis for making this empirical knowledge a part of the process of manyadahi talempong. Heddi Shri HamimsaPutra (2001) in his work entitled Strukturalisme Levi-Strauss, Mitos dan Karya Sastra, includes a section on the topic of myth according to the view of Levi-Strauss.

The literature used as an academic reference in this research is studied as a reference for explaining the method and procedure for manyadahi talempong and the effect of sadah on creating an aesthetical quality of talempong sound that is pleasing to the ear. It should be emphasized that none of the literature used as a reference in this research was found to have the same focus on talempong as the material object, thus ensuring the originality of this research.

\section{Research Method}

The method used in this research is a combination of qualitative ideas and an experimental method. The qualitative method played an important role in the collection of data related to the ritual of manyadahi talempong, and the researcher acted as the research instrument. Data collection was carried out through interviews and audio, visual, and audio-visual recordings. An experimental method was used to find the different frequencies of talempong pitches and the duration of the talempong sound prior to and after applying the sadah. Subsequently, this method was assisted by other software such as Cool Edit Pro version 2.0, to obtain a concrete picture about the pitch levels - frequencies - of the talempong. Another measurement used was the cent, to measure differences in frequency between one talempong sound and another. Hastanto writes that in the science of acoustics, the distance or interval between two pitches is measured in cents (Hastanto, 2012: 20). This distance can be measured by means of a logarithmical calculation, with the aid of computer technology which uses the German-made software Sengpielaudio that can be operated on line. Other software used included 
Nuendo 3, for measuring the duration of the sound waves.

\section{DISCUSSION}

\section{Procedure and Method of Manyadahi Talempong}

\section{Between Myth and Ontological Culture}

The need to implement the practice of manyadahi talempong may be due to a number of factors, which include the presence of: (1) baduang; (2) danciang or dangiang. First, baduang (or pakak) occurs when the talempong no longer produces a sound which is characteristic to that of a talempong when struck. Second, danciang or dangiang is the reverberationor additional sound that accompanies the main sound of a talempong when it is struck, and the talempong continues to sound for a long duration. The manyadahi talempong ritual takes place on a particular day and at a particular time, namely on a Thursday evening (patang Kamih-malam Jumaik). The local community believes that this is the time when God's grace descends from the sky.

The requirements or concoction used in manyadahi talempong include: (1) limau/asamkapeh or lime fruit; (2) aiabatamu, or water that is taken from two different springs which meet and become one at a particular place; (3) aiamalampatang Kamih, or water from a spring that is collected on a Thursday evening; and (4) sadah, a type of chalk made from snail shells, and usually known as "sadah for eating" because of its use in betel chewing. The procedure for manyadahi talempong involves the following methods: (1) performing ritual ablution; (2) reading a mantra; (3) combining the water (aiabartamu + aiapatang Kamih) with the lime (limau/asamsaiktujuah [seven cuts]); (4) combining the sadah with the water mixture (5) taking thetalempong to be smeared with sadah; (6) checking the sound of the talempong; and (7) malimaui (applying the lime).

First, ritual ablution is performed to cleanse the body, because in essence, manyadahi talempong is considered to be a holy, sacred ritual in which a request is made to Almighty God that the talempong may produce a sound which fulfils a certain aesthetical quality. A sound with a good quality refers to the miracles of the prophets - in the case of the voice, to the prophet David. Fatchur Rochman writes that God awarded the prophet David with a gift or miracle of a sweet-sounding voice that was pleasing to the ears of humans, spirits, birds, mountains, wind, and leaves, all of which were delighted by the sound of the prophet David's voice. Every prophet had a particular miracle or gift (an extraordinary ability) which was a sign of their prophethood. In the case of Joseph, it was his face; in the case of Solomon, his kingship; and in the case of Muhammad, his light (Rochman, 1995: 219).

Second, a mantra is read for the prepared concoction, which begins with: (1) istighfar, recited 3 times astagfirullah'al'azim, asking God for forgiveness; (2) reciting the 2 parts to the creed of Islam 3 times asyhaduallaillahaillallahwaas'adhu'annamuhammadarasulullah; (3) reading surah Al-Fatihah; and (4) reciting Alhamdulillahirabil'alamin with the following text.

Bismillahirrahmanirrahim
YaDautterlalulalai(oh David, too remiss)
Tujuahlapihpitalolangik (seven layers of heaven)
Tujuahlapihpitalobumi (seven layers of earth)
Mangkotabuakmangkolanteh (to penetrate then pass through)
Kanai bunyitalempongku (find the sound of mytalempong)
Allahiwalssallam (Allahiwasallam)
PakaipitnangNabiDaud (use the mystical knowledge or suggestion [pitunang] of the prophet David)
Aia ilia tahanti-hanti (water stops flowing downstream)
Mandangabunyitalempongku (hearing the sound of my talempong)
PakaipitnangNabiDaud (use the suggestion of the prophet David)
Allaihiwassallam (Allaihiwassallam)
Tasengeangmaikdalamkubua (smiling is the corpse in the grave)
Mandangatalempongku (hearing mytalempong)
Sadangkananakbidodaridalamsarugo (while the cherubim in heaven)
Lagiterlatik, lagitertukik, lagiterlansik (fascinated, swooping, amazed)
Mandangabunyitalempongku (hearing the sound of mytalempong)
Kununlahmantagisidanganakmanusia (said to be the aura of all human children)
Ndakkarindumandangabunyitalempongku (not longing to hear the sound of my talempong)
Pakaipitunang Nabi Daud (use the suggestion of the prophet David)
Kabuabarakaik Laillahaillallah (fulfilled byLaillahaillallah)

The above text of the mantra gives us an indication of the mystification in combining elements of culture and religion. This is clear in the narrative of the text composed in the form of a mantra, beginning with the word bismillahirrahmanirrahim (in the name of God, the most gracious and most merciful). It continues with the words of David, the seven layers of heaven and seven layers of earth, the sound of the talempong, the mystical knowledge [suggestion/pitunang] of the prophet David ... the smiling corpse in the grave, hearing the sound of 
the talempong ... owing to Laillahaillallah. The first word is bismillah and the final word is laillahaillallah, which means this mantra is encased in a religious narration with cultural content.

Third, the water (aiabatamu + aiapatangKamih) is combined with the lime (limau/asam saiktujuh) in a dish or other vessel. This mixture of water and acidic lime is used to dissolve the sadah and the talempongis wiped with lime after it has been smeared with sadah. In the description above of the first three steps, there is a clear indication of myth encased in religious knowledge. C.A. van Peursen,in his book Strategi Kebudayaan (1994), states that myths are stories which offer certain guidance or direction to a group of people - human behaviour. Through myths, people can participate in the course of their events (Peursen, 1994: 37). It is a fact that the role of talempong elders is important in their participation in the manyadahi talempong ritual as they endeavour to determine the aesthetical standard of talempong as a music system and a musical system.

It is important to realize that the understanding of myth in the structuralism of Levi-Strauss is not the same as the understanding of myth as is commonly used in the understanding of mythology. In accordance with the general view of anthropologists, Heddi Shri Hamimsa-Putra explains that the understanding of myth from the perspective of Levi-Strauss does not need to be contrasted with history or reality, because the difference in meaning between the two concepts seems increasingly difficult to defend in current times (Hamimsa-Putra, 2001: 77). What one group or community considers to bea historical account of events that really took place may be considered by another community as no more than a fairy tale or legendthat cannot be accepted as truth; myth in the context of Levi-Strauss is none other than fairy tale or legend (Hamimsa-Putra, 2001: 77). A fairy tale is a story that was born from human imagination or fantasy, even though elements of this fantasy originate from events that really took place, such as in the manyadahi talempong ritual, which is connected to the power of suggestion of the prophet David. In such events, we find things that do not make sense or are not found in our day to day lives.

In myths we find interesting contradictions. There are numerous events in myths that we cannot and would not believe could really happen in daily life. Heddi Shri Hamimsa-Putra states that anything and everything may happen in a myth, ranging from something that makes sense to something that partially makes sense to something that makes no sense at all. Therefore, we often feel that there appears to be no logic at all in a myth (Hamimsa-Putra, 2001: 82). This is the case in the myth of the concept of suggestion (pitunang) in the manyadahi talempong ritual.

Fourth, the sadah is combined with the water that has already been mixed to a certain viscosity in a prepared dish or vessel. Next, one by one the talempong are smeared with the sadah solution on the inside surface. The talempong taken as a sample for this research consist of a set of six talempong, known as anamsalabuhan referred to with the code T1, T2, T3, T4, T5, and T6. Thetalempong pitch order from T1, T2, T3, T4, T5, to T6 can be described as talempong as a music system. The pitch levels of each of the talempong- T1, T2, T3, T4, T5, and T6 -are determined based on the knowledge and musical experience of the talempong elders, a practice they call mangkoanbunyi (a system of tuning). Andar Indra Sastra writes that mangkoanbunyi is practiced based on the musical sensitivity of the talempong elders which is used as a reference. This standard reference is founded on their experience and musical knowledge about the difference in pitch levels in the talempong music system (Sastra, 2016: 17). The different pitch levels of the talempong are a guideline for identifying the talempong pairs, talempong Jantan; talempong Paningkah, and talempong Pangawinan. At this point we are talking about talempong as a musical system.

Talempong as a musical system consists of three pairs of talempong: 6 and 1 are known as talempong Jantan; 5 and 3 are called talempong Paningkah; and 4 and 2 are called talempong Pangawinan. In an article published in Jurnal Humaniora, Andar Indra Sastra (2017) writes that the talempong pair T6 and T1 always begins the work and acts as the leader in a performance. As the leader, the talempong pair T6 and T1 plays the opening melody and guides the imagination of the other players who play the talempong pairs T5 and T3 and T4 and T2 so that they are able to identify the type of melody (guguah) they are to play (Sastra, 2017: 62).As the leader, the musician who plays the talempong pair T6 and T1 not only has the role of determining the type of guguah to be played but is also responsible for controlling the tempo (danyuik) of the performance, although the dynamics, or kareh-lunak, are controlled by the talempong Pangawinan pair.

Fifth, the talempong are taken to be smeared with sadah. Before this is done, the talempong are first cleaned with water to get rid of the remains of any previous sadah, and then wiped dry with a cloth. After the talempong have been cleaned and dried, they are held in the hand (direnjeang) and struck one by one to hear the sound quality. Depending on the sound produced, it is decided which part of the talempong needs to be smeared with sadah and what pattern is used to manyadahi talempong.

Sixth, the sound is checked after all the talempong have been applied with sadah. Each talempong is held in the hand and struck in turn to listen to the individual sound. This is done to see whether the sound produced meets the desired aesthetical standard. If any of the talempong does not produce the quality of sound that is hoped for, it will usually be reapplied with sadah until the sound produced is good and meets the expectations of the person performing the manyadahi talempong. In other words, a cross-check is performed to obtain the desired sound 
quality, according to the two indicators mentioned in the previous section. Seventh, the talempong are applied with lime, or rinsed, as a way of finishing the task, and they are then ready to be played.

Based on the analysis of manyadahi talempong, it can be concluded that the purpose of manyadahi talempong is to preserve the stability of the talempong sound in accordance with the desired aesthetical qualityaccording to a particular musical standard. Suka Harjana states that sound quality is usually concerned with how good-bad, beautiful-ugly a sound is when it reaches our ears (Harjana, 1983: 49). In addition, manyadahi talempong also includes an element of belief that this ritual will produce a talempong sound which captivates anyone who hears it - the local community call this malakekan pitunang (giving suggestion), or bestowing magical powers on thetalempong. According to the informants and members of the local community interviewed, talempong that have been smeared with sadah and lime - or given suggestion (pitunang)- will remain in the hearts and memories of the people who hear it, even when the talempong is no longer being played (Dt. Sampono, interview, 29-10-2016). This phenomenon may be described as an aesthetical experience of an object which exudes aesthetical value. The Liang Gie describes aesthetical value as the ability of an object to cause an aesthetical experience in the person observing or listening to the object (Gie, 1983: 51).

If we look at the indication of myth - narration - that appears in the procedure and method for manyadahi talempong it is interesting to discuss this from the perspective of (rational-modern) ontological culture. Why so? Because there are a number of points which are of interest when studied from an ontological cultural perspective, such as: (1) aiabatamu, water taken from two different springs which meet and become one at a particular place; (2) aiamalampatangkamih, or water from a spring that is collected on a Thursday evening; (3) reading the mantra; and (4) applying the lime (malimaui).

First, aiabatamu, the water collected from two different springs which meet and become one at a particular place, is one of the requirements for manyadahi talempong. In terms of the function for beautifying the sound of the talempong, it cannot be explained from an ontological cultural perspective why the water needs to be collected from this specifically designated spot rather than another source. Here, aiabatamu is positioned as a myth that has become part of the manyadahi talempong ritual. Second, aiamalampatangkamih is one of the materials that must be present in the manyadahi talempong ritual. The first and second requirements are of equal status - both are water but have a different source, event, and meaning. The different event is that according to talempong elders, this water possesses supernatural powers and should therefore be used to dissolve the sadah. This sadah solution is used to improve the sound quality of the talempong.

Ontologically, the sadah solution that contains chemical properties can be used to improve the quality of the talempong sound. By experimenting, it was proven ontologically that by using such a solution of sadah, there was indeed a change in the quality of the talempong sound. See Table $\mathbf{2}$ below for a summary of the duration of talempong sounds after the process of mangkoanbunyi andthe application of sadah. Third, reading a mantra which uses the suggestion of the prophet David; it is believed that this narration provides suggestion or spiritual power for the talempong sound. Fourth, the application of lemon (malimaui) is the final part of the ritual procession, and includes wetting the talempong with a mixture of aiabatamu and aiapatang Kamih, along with various other ingredients. The third and fourth parts of the ritual contain mystical elements which combine elements of both culture and religion. Of course, it is difficult to prove in quantitative terms, from an ontological cultural perspective, the change in talempong sound, which produces a sense of pleasure - based on the laws of cause and effect, since the reality is in a noumenal domain. Meanwhile, on this level, it is important to remember that the third and fourth sections, knowledge and ontological culture - are connected through cause and effect.

\section{Physical Quality: Talempong Sound and Aesthetical Quality}

The physical quality of the talempong is important in its capacity as a sound source and also a resonating chamber. Aesthetically, the physical quality and sadah play an important role in improving the quality of the talempong sound. The goal of manyadahi talempong in the form of a simple ritual is to achieve an aesthetical sound quality that meets the musical standard of talempong elders in Minangkabau. Deni Junaedi defines aesthetics as "the study of a process that occurs between a subject, object, and the value contained in the object, including the experiences, properties, and parameters of attractiveness and unattractiveness" (Junaedi, 2018: 14). In the case of the manyadahi talempong ritual, we are studying the process that occurs between the subject and the object. The relationship between a subject and an object, according to Martin Suryajaya, includes seeing, hearing, and feeling (Suryajaya, 2015: 1); in this case, the manyadahi talempongritual is the material object. In addition to discussing the relationship between the subject and the object, aesthetics, according to Martin Suryajaya, is not only concerned with value but also with aesthetical experience, the ontological status of a work of art, and the relationship between art and the community (Suryajaya, 2015: 3).

With regard to manyadahi talempong as a material object, in aesthetical terms the discussion is limited to the relationship between the subject and the object within the boundaries of procedure and method, as well as the physical quality:talempong sound and aesthetical quality. The reason for this limitation is not because the writer does not wish to discuss the broader topic of aesthetics, as explained by Deni Junaedi and Martin 
Suryajaya, in its entirety, but rather due tothe consideration of the limited space available for the publication of this article.

Aesthetically (in terms of beauty), the relationship between the subject and object places more emphasis on the construction of the ritual in connection with the sadah and the talempong - specifically the physical quality of the material object. The physical quality of the talempong and the sadah play an important role in altering the aesthetical quality of the talempong sound. The sound source of the talempong is the momong, or pencon (bossed knob) on top of the instrument. The talempong will produce a sound when the mallet (pangguguah) touches the momong with a particular force. When the momong produces a sound, the entire physical structure of the talempong also vibrates. This vibration causes the air around the sound source to vibrate. The vibration in the air caused by the momong is influenced by the resonating chamber, or the physical shape of the cavity inside the talempong. The resonating chamber and physical quality have a relational connection in terms of their function to produce a good sound on the talempong. For a clearer picture, see the illustration below.

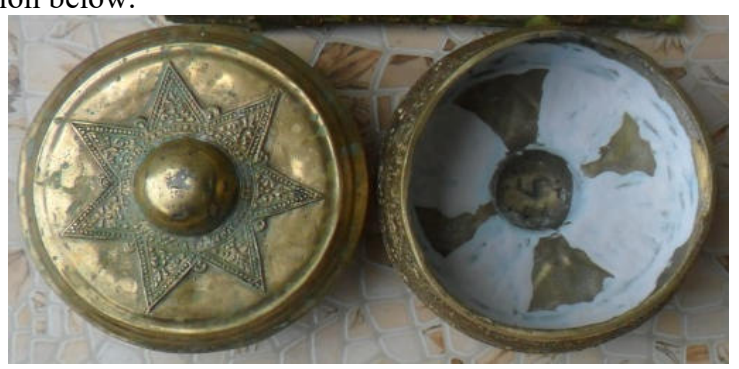

Picture 1. Physical structure of thetalempong, sound source, and resonating chamber

(Photo: Documentation by A ndar, 2016)

Whether the sound of a talempong can be categorized as good or bad depends on the identification of three elements: rono (sound colour), sipongang (reverberation), and duration of the sound.

a. Rono (colour)

Rono in relation to sound is associated more with the auditory impression conveyed by the sound to the listener. The elements that distinguishe one talempongsound from another are rono and the way the instrument is struck. A talempong sound with a good rono is one that produces a rounded sound with not too many sub-tones. Subtones are the additional sounds produced besides the main pitch. The cause of these sub-tones may be due to a crack on the talempong. A cracked instrument will produce multiple sub-tones or additional tones to the main pitch when the talempong is struck (diguguah). These multiple sounds may affect the quality of the rono. In other words, the rono of the talempong is determined by a number of factors, including material, shape, and the different ways of playing the sound source.

\section{b. Sipongang}

Sipongang (reverberation) is also sometimes known as dangiang, and refers to the quality of the talempong sound as it resonates or reverberates after it is struck. A talempong with a good quality sound can be identified by a sipongang sound that does not buzz, nor can it be described as pakak or baduang. Pakak does not mean there is no sound produced but rather is related to the auditory impression of a sound that no longer represents the rono of the talempong. Through the sipongang and pakak sound produced, talempong elders are able to identify talempong sounds with a good or bad quality of sound.

In order to obtain a good sipongang sound, the sound produced by a talempong needs to be muted in order to create a sound that meets the particular demands of musical taste. Talempong elders do this by smearing a solution of chalk (manyadahi) to the inside of the talempong, according to the level of damage or distortion in the talempong sound. The word manyadahi comes from the wordsadah, with the additional prefixma (denoting an active verb) and the suffix $i$, which indicates something is being done to the object, in this case the practice of 'manyadahi talempong'. Dt. Samponostates that the use of sadah to mute the sound of the talempong is related to the belief - which contains a mystical element - thatit enables the talempong to produce a sound which is pleasant to hear and captivates the listener (Dt. Sampono, interview, 06-06-2015). Whether or not a sound is considered pleasing to the ear can be identified by the presence of a sipongang sound that does not disturb the musical feel when the talempong instrument is played.

The part of the talempong that is applied with sadah is the inner surface. There are two forms of manyadahi talempong: (1) the inside of the momong is smeared with sadah and marked with a cross; (2) a cross is marked inside the instrument without applying sadah to the inside of the momong. In the first case, the inside of the momong is applied with sadah with the addition of a cross-shaped mark. This is done if the talempong sound produced by the momong is not good. The cross-shaped marking functions to preserve the stability of the sound and to dampen the duration of the sipongang so that it is not too long. Suka Harjana defines duration as the length of time a note continues to sound (Harjana, 1983: 48). 
In the second case, only a cross-shaped mark is applied to the inside of the instrument, without applying sadah to the inside of the momong. This is an indication that the momong is still producing a good sound but its physical vibrations need to be muted, by applying a cross-shaped mark, to ensure a balanced sound and shorten the duration of the sinpongang. The process and pattern for manyadahi talempong can be seen in the picture below.

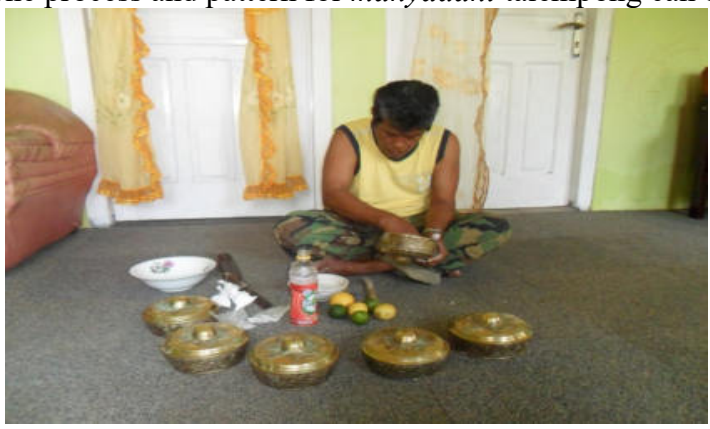

Picture 2. Process of manyadahi talempong

(Photo: Documentation by Andar, 2015)

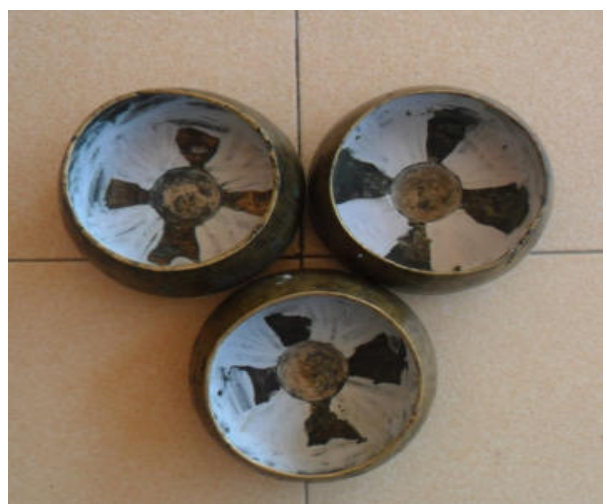

Picture 3. Pattern of manyadahi talempong

(Photo: Documentation by Andar, 2015)

The purpose of using sadah to adjust the sipongang of the talempong is to improve its aesthetical quality in accordance with the wishes of the talempong elders. This not only involves a physical procedure but must also be accompanied by the non-physical element of the ritual,which talempong elders believe to be of great importance. Efforts to improve or maintain the sipongang sound of the talempong are required in order to preserve the aesthetical quality of the talempong sound.

\section{c. Sound Duration}

Sound duration refers to the time or length of time the sound continues to reverberate after the talempong instrument is struck. Through an experiment using a talempong that was considered to be of good quality, it was discovered the sound duration suitable for fulfilling the musical requirements of talempong elders. The experiment involved four stages of activities. First, a good quality talempong set was prepared by making a direct purchase from a talempong maker in Nagari Sungai Pua - Luhak Agam (see the illustration on the following page), and thetalempong sounds were recorded using a digital voice recorder before the talempong elders tuned the instruments, a practice known as mangkoanbunyi. Second, the mangkoanbunyi talempong was performed based on the musical feel and musical standard of the talempong elders, and then the talempong sounds were recorded again. Third, the ritual of manyadahi talempong was performed, at which time the talempong elders "breathed spirit" - to use Hastanto's term (Hastanto, 2012: 6) into the physical form of the talempong. Fourth, the sounds of the talempong were recorded again after the process of manyadahi was finished.

The results of the recordings of talempong sounds were processed using the digital software Cool Edit Pro version 2.0, and Nuendo 3. The software Nuendo 3 used in this research helped to provide a concrete picture about the fundamental frequencies, sound duration, and overtone series, which were displayed on a diagram. Measurements of sound duration were taken before and after the sadah was applied, and the results can be seen in the table below. 


\begin{tabular}{|c|c|c|c|c|c|}
\hline No & $\begin{array}{c}\text { Position of } \\
\text { Primary } \\
\text { Pitch }\end{array}$ & $\begin{array}{c}\text { Frequency } \\
(\mathrm{Hz})\end{array}$ & $\begin{array}{c}\text { Fundamenta } \\
\text { 1 Frequency } \\
(\mathrm{Hz})\end{array}$ & $\begin{array}{c}\text { Sound } \\
\text { Duration } \\
\text { (Seconds) }\end{array}$ & $\begin{array}{c}\text { Overtone } \\
\text { series } \\
\text { (Hertz) }\end{array}$ \\
\hline 1 & 2 & 3 & 4 & 5 & 6 \\
\hline T1 & A\#4-31 & 357.76 & A\#4 & 1.768 & $459 \mathrm{~Hz}$ \\
\hline T2 & C\#5-47 & 539.43 & C\#5 & 1.915 & $542 \mathrm{~Hz}$ \\
\hline T3 & D\#5-28 & 612.12 & D\#5 & 2.138 & $612 \mathrm{~Hz}$ \\
\hline T4 & E5-9 & 655.63 & E5 & 2.281 & $656 \mathrm{~Hz}$ \\
\hline T5 & C6+22 & $1060-5$ & C6 & 1.486 & $1061 \mathrm{~Hz}$ \\
\hline T6 & G5+11 & 789.01 & G5 & 1.288 & $786 \mathrm{~Hz}$ \\
\hline
\end{tabular}

Table 1.Sound duration of talempong before the application of sadah

Table 1 above clearly shows that based on the fundamental frequency, the duration of the talempong sounds varies - see column 5. The sound waves produced by the basic frequency have a series of overtones. These overtones appear in multiple frequencies that continue until they are too high for the human ear to hear. Through an analysis of the audio system used in the Nuendo 3 program, the overtone series of each talempong can be observed, as seen in the following diagrams.

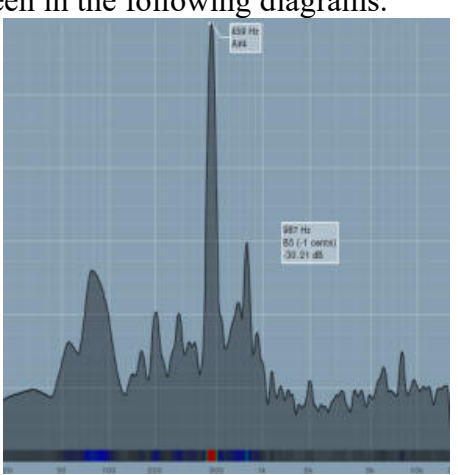

Overtone Series T1

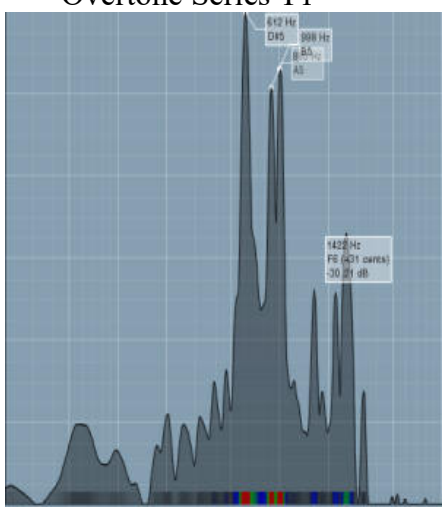

Overtone Series T3

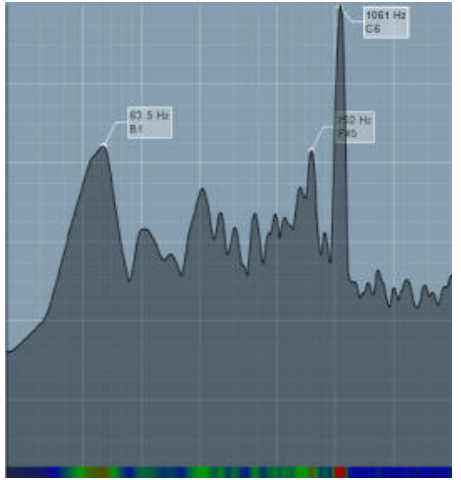

Overtone Series T5

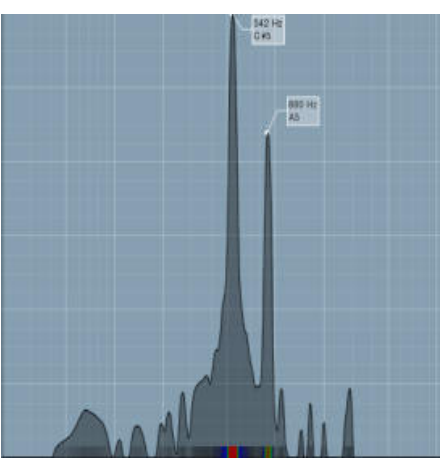

Overtone Series T2

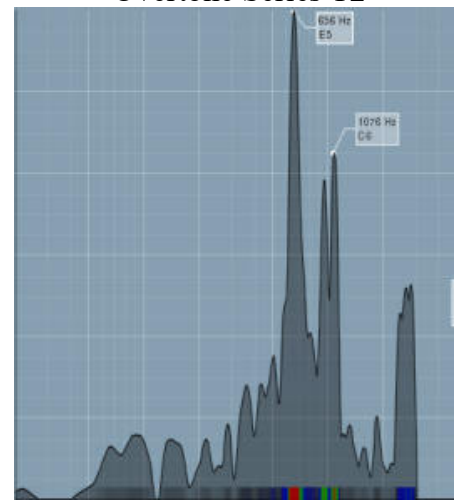

Overtone Series T4

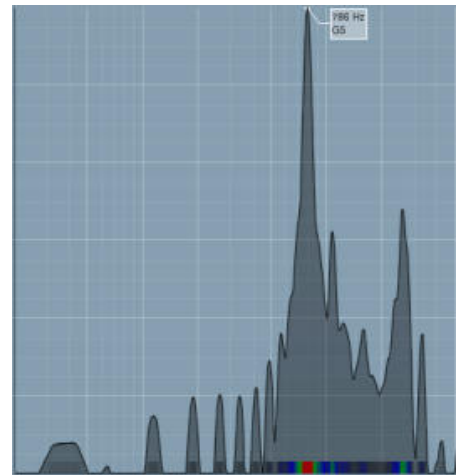

Overtone Series T6

Picture 4. Overtone series of six talempong pitches before the application of sadah 
Picture 4 above shows that the overtone series is not a stable phenomenon, meaning that the multiple sounds produced above the fundamental frequency are not in multiples of the fundamental frequency as expected. For example, if the fundamental frequency is at the position A4 $456 \mathrm{~Hz}$, the overtone series should be at the position of $912 \mathrm{~Hz}$ or in multiples of the frequency $456 \mathrm{~Hz}$. However, each of the six overtone series measured using Nuendo 3 software displays different characteristics. After the process of mangkoanbunyi (tuning) and the manyadahi talempong ritual were finished, there was found to be a change in the musical structure and duration of the talempong sounds produced by the fundamental frequencies, as shown in the table below.

\begin{tabular}{|c|c|c|c|c|c|}
\hline No & $\begin{array}{c}\text { Position of } \\
\text { Primary } \\
\text { Pitch }\end{array}$ & $\begin{array}{c}\text { Frequency } \\
\text { (Hz) }\end{array}$ & $\begin{array}{c}\text { Fundamenta } \\
\text { 1Frequency } \\
\text { (Hz) }\end{array}$ & $\begin{array}{c}\text { Sound } \\
\text { Duration } \\
\text { (Seconds) }\end{array}$ & $\begin{array}{c}\text { Overtone } \\
\text { Series } \\
\text { (Hertz) }\end{array}$ \\
\hline 1 & 2 & 3 & 4 & 5 & 6 \\
\hline T1 & A\#4+46 & 452.06 & A\#4 & 1.214 & $449 \mathrm{~Hz}$ \\
\hline T2 & C\#5-48 & 539.41 & C\#5 & 1.216 & $538 \mathrm{~Hz}$ \\
\hline T3 & D\#5+28 & 613.64 & D\#5 & 1.296 & $604 \mathrm{~Hz}$ \\
\hline T4 & E5-9 & 656.63 & E5 & 1.225 & $648 \mathrm{~Hz}$ \\
\hline T5 & F\#5+20 & 748.20 & C6 & 1.112 & $745 \mathrm{~Hz}$ \\
\hline T6 & G5-11 & 783.45 & G5 & 1.040 & $772 \mathrm{~Hz}$ \\
\hline
\end{tabular}

Table 2.Duration of talempong sound after mangkoanbunyi and the application of sadah

Table 2 above shows the change in position of the primary pitches of T1 and T5, from T1 at the positionA\#4-31, and T5 at the position C6+22 (see table 1). After the process ofmangkoanbunyihas been carried out by the talempong elders, T1 becomes A\#4+46 and T5 becomes F\#5+20 - see column 2 in table 2 above. Another important change occurs in the duration of the talempong sound before and after the application of sadah. After the sadah has been applied, the duration of the talempong sound becomes shorter - see column 5 in table 2 above. This means that the smaller the frequency of the vibration of the talempong sound, the longer the sound wave formed. In other words, the lower the talempong pitch, the longer the time required until the talempong sound is no longer audible to the human ear. On the contrary, the greater the frequency of the talempong sound, or the higher the pitch, the shorter the time duration - see columns 4,5 , and 6 on table 2 above. According to Jufri, the ideal sound duration on the talempong must match the reverberation of the pitch level of each instrument (Jufri, interview, $24-11$ - 2018). This means that the longer the reverberation of a talempongsound, the longer the time needed, and the shorter the reverberation of a talempong pitch, the shorter the duration needed. The sound waves that originate from the fundamental frequency have an overtone series and can produce multiple additional pitches. By analyzing the audio system through Nuendo 3 software, the overtone series of talempong pitches can be observed in the following diagrams. 


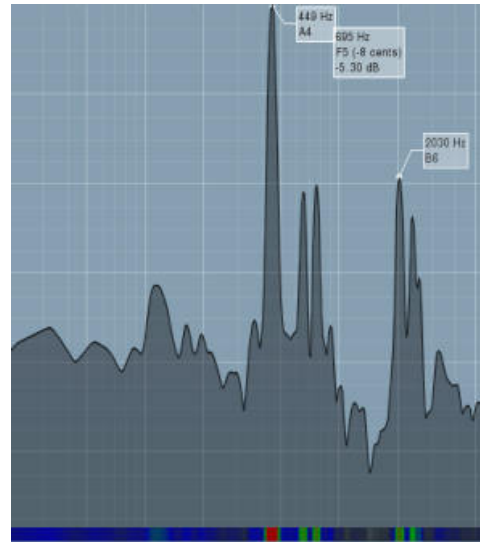

Overtone Series T1

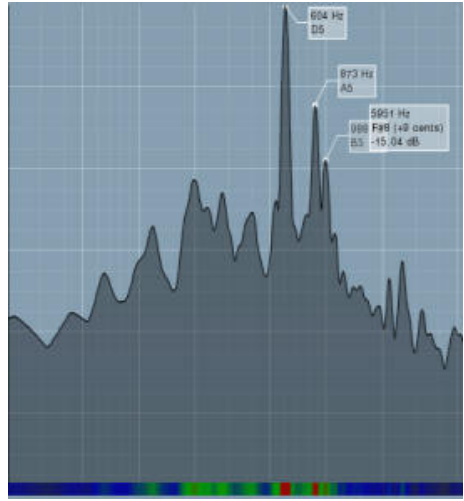

Overtone Series T3

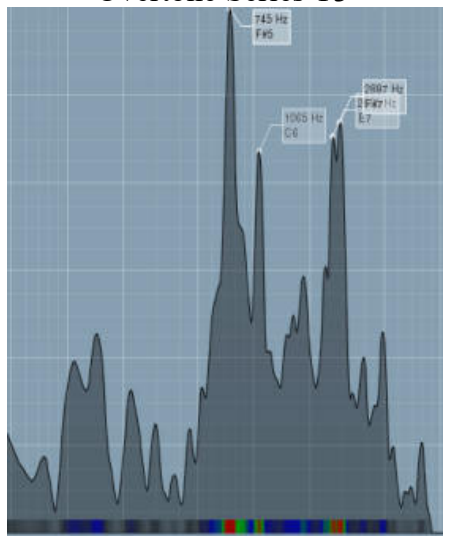

Overtone Series T5

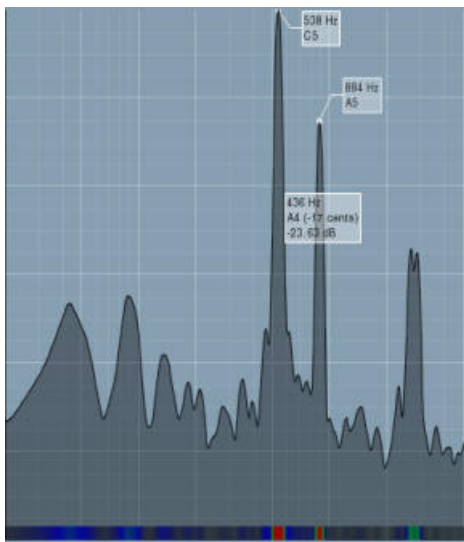

Overtone Series T2

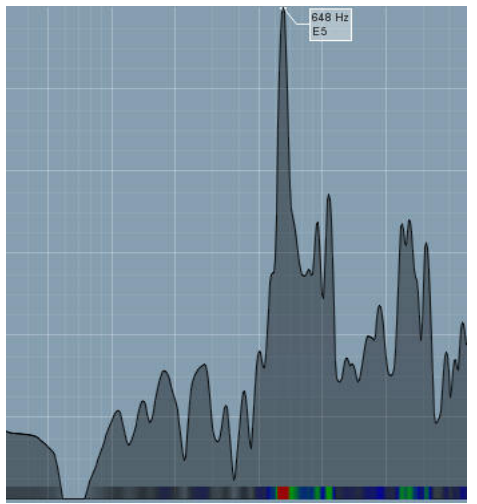

Overtone Series T4

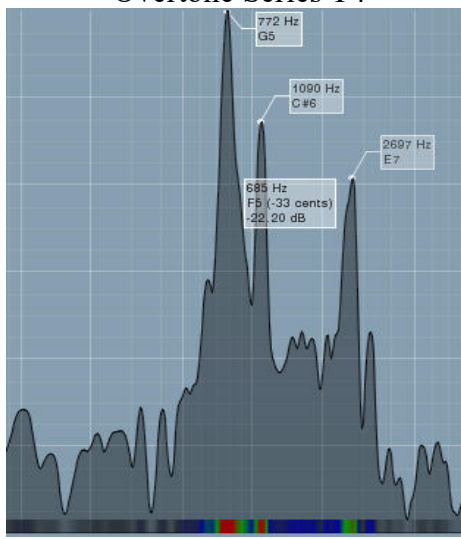

Overtone Series T6

Picture 5. Overtone series of six talempong pitches after the application of sadah

The diagrams above show that the overtone series of the primary pitches do not display multiples of the fundamental frequency in the series of additional sounds produced when the talempong is struck. This is evident from the sound peaks that follow the primary pitches, which are different for each talempong. T1 has a fundamental frequency of $449 \mathrm{~Hz}$ in the tonal area A4, while thesubsequent overtoneserieshas a frequency of $695 \mathrm{~Hz}$ in the tonal area F5, and $2030 \mathrm{~Hz}$ in the tonal area B6. The primary pitch of T2 is recorded as $638 \mathrm{~Hz}$ in the tonal area $\mathrm{C} 5$, with the overtone series $884 \mathrm{~Hz}$ in the tonal area $\mathrm{Ab}$, and $736 \mathrm{~Hz}$ in the tonal area A4. The primary pitch of T3 is recorded as $604 \mathrm{~Hz}$ in the tonal area D5, and the subsequent tones are recorded as $873 \mathrm{~Hz}$ in the tonal area $\mathrm{Ab}$, and $5951 \mathrm{~Hz}$ in the tonal area $\mathrm{F} \# 8$. The primary pitchof $\mathrm{T} 4 \mathrm{is} 648 \mathrm{~Hz}$ in the tonal area $\mathrm{E} 5$, and does not record any subsequent pitches. The primary pitch of T5 is $745 \mathrm{~Hz}$ in the tonal area F\#5 and its subsequent pitches are recorded at the frequency of $1065 \mathrm{~Hz}$ in the tonal area C6, and $2897 \mathrm{~Hz}$ in the tonal area F\#7. The primary pitch of T6 is recorded as $772 \mathrm{~Hz}$ in the tonal area G5, with the subsequent pitches $1090 \mathrm{~Hz}$ in the tonal area $\mathrm{C} \# 6,685 \mathrm{~Hz}$ in the tonal area F5, and $2697 \mathrm{~Hz}$ in the tonal area E7. This kind of sound duration is an important component in the performance of talempong renjeanganamsalabuhan (set of talempong) for 
achieving satisfaction and a high quality of performance.

\section{CONCLUSION}

Traditionally, sadah is empirical knowledge that has been used by women in Minangkabau for many generations. This same knowledge has been inherited by talempong elders for a different purpose, namely to obtain an aesthetical quality in the sound of talempong. This empirical knowledge about the use of sadah is also complemented by mystification which is directed towards the voice of the prophet David. Through a qualitative and experimental method, it is found that acoustically, sadah has the ability to preserve the aesthetical quality of talempong sound in accordance with the musical standard of talempong elders in Minangkabau.

\section{References}

Hardjana, Suka. (1983). Estetika Musik. Jakarta: Departemen Pendidikan dan Kebudayaan.

Heddi, Shri Hamimsa-Putra. (2001). Strukturalisme Levi-Strauss, Mitos dan Karya Sastra. Yogyakarta: Galang Press.

Hastanto, Sri. (2012). Ngeng \& Reng: Persandingan Sistem Pelarasan Gamelan Ageng Jawa Dan Gong Kebyar Bali. Surakarta: ISI Press.

Junaedi, Deni, 2018. "Kebenaran Epistemologis Pada Nilai Estetis Seni Untuk Ibadah". Presented at Seminar Estetika \#4with the theme CITA RASA Seni Rupa di Era Pluralisme Estetik (18-19 July at ISI Padangpanjang 2018), p.14.

Rochman, Fatchur. (1995). Kisah-Kisah Nyata dalam Al-Qur'an. Surabaya: Apolo.

The Liang Gie. (1983). Garis Estetik-Filsafat Keindahan. Yogyakarta: Penerbit Super Sukses.

Sastra, Andar Indra. (2016). Estetika Talempong Renjeang. Padangpanjang: Penerbit Institut Seni Indonesia Padangpanjang.

2018. The Aesthetics of a Three-Way Pattern: The Musical Concept of Talempong Renjeang and The Social System of The People of Luhak Nan Tigo Minangkabau. Humaniora, Vol. 29. Number 1. February 2017. 61-71.

Suryajaya, Martin. (2015). SejarahEstetika: Era Klasik Sampai Kontemporer. Jakarta: Gang Kabel.

Peusen, C.A. van. (1994). Strategi Kebudayaan. Terj. Dick Hartoko (fifth print). Yogyakarta: Penerbit Kanisius.

\section{Informants}

Dt. Sampono (61), entrepreneur; talempong elder from the group Ateh Guguak Nagari Pitalah Bungo Tanjuang Luhak Tanah Data, interviewed in 2018.

Jufri, (53), Master of Arts, Composer, Art Observer, Teacher in Karawitan Study Program, Institut Seni Indonesia (ISI) Padangpanjang, interviewed in 2018 